\title{
Mavi Işık Maruziyetinin Sirkadiyen Ritim ve Beslenme Üzerindeki
} Etkisi

\section{Blue Light Exposure Effect on Circadian Rhythm and Nutrition}

\author{
Asghar Amanpour ${ }^{1 *}$, Sevde Kahraman ${ }^{1}$, Büşra Çınar ${ }^{1}$, Fatma Çelik ${ }^{1}$ \\ ${ }^{1}$ Biruni Üniversitesi, Sağlık Bilimleri Fakültesi, Beslenme ve Diyetetik Bölmü, Zeytinburnu, İstanbul, Türkiye \\ e-mail: asghar.amanpour@gmail.com, sevde.kh@gmail.com, 160502014@st.biruni.edu.tr, fcelik@biruni.edu.tr \\ ORCID: 0000-0001-9783-691X \\ ORCID: 0000-0003-4562-1081 \\ ORCID: 0000-0001-9908-2509 \\ ORCID: 0000-0002-7553-8687 \\ *Sorumlu yazar/ Corresponding Author: Asghar Amanpour \\ Gönderim Tarihi / Received: 04.03.2021 \\ Kabul Tarihi / Accepted: 20.08.2021 \\ DOI: $10.34087 /$ cbusbed.891351
}

\begin{abstract}
$\ddot{O} \mathbf{z}$
Latin dilinde circa: yaklaşık, dies: bir gün karşılığındadır. Sirkadiyen ritim, 24 saatte bir kendini tekrar eden periyodik kalıplardır. Sirkadiyen ritimler günlük ritimlerden farklı olarak endojen olarak üretilir ve dış zaman işaretleri olmasa bile kendilerini devam ettirir. $\mathrm{Bu}$ sistemin yürütücüsü, ön hipotalamusun suprakiazmatik nükleusta (SCN) bulunan ana saattir. Mavi renk olarak algılanan kısa dalga boyları, çoğu biyolojik ve psikolojik ritim dahil olmak üzere sirkadiyen sistem için en güçlü senkronize edici ajandır. Diğer uyarıcılar; sıcaklık, yemek yeme/açlık, dinlenme/aktivite ve sosyal ipuçlarıdır fakat bu uyarıcıların etkileri ışık ile karşılaştırıldığında çok daha zayıftır. Sirkadiyen ritim organizmaların ideal fonksiyonu için önemlidir. Sirkadiyen uyku-uyanıklık bozuklukları veya kronik yanlış hizalanma sıklıkla psikiyatrik ve nörodejeneratif hastalıklara yol açabilmektedir. Nispeten yakın tarihli teknolojik, beslenme ve yaşam tarzı gibi çevresel değişiklikler, birçok bireyi sirkadiyen sistem bozukluklarına yatkın kılmaktadır. Yapay aydınlatma, yüksek hızlı trans-meridyen hareketi ile indüklenen jet-lag, vardiyalı çalışma ve enerji içeriği yüksek yiyeceklere yirmi dört saat erişim, sirkadiyen sistemi düzensiz hale getirerek modern toplumların sağlığını olumsuz yönde etkileyebilecek birkaç faktördür. Mavi ışı̆̆a maruz kalma ise gün içinde organizmanın refahını, uyanıklığını ve bilişsel performansını korumak için önemli olsa da, yatmadan hemen önce düşük yoğunluklu mavi ışığa kronik maruziyetin uyku kalitesi, sirkadiyen faz ve döngü süreleri üzerinde ciddi etkileri olabilmektedir. Modern toplumda sosyal jet-lag ve gece mavi ışığa maruz kalma artışı, sirkadiyen yanlış hizalama ve uyku bozukluklarının önemli sağlık sorunları olarak ortaya çıktığını göstermektedir.
\end{abstract}

Anahtar Kelimeler: Beslenme, Mavi 1şık, Melatonin, Metabolizma, Sirkadiyen bozulma, Sirkadiyen ritim.

Abstract
Circadian rhythm, comes from circa: approximate and dies: one day in Latin language, periodically repeats itself every 24 hours. Unlike daily rhythms, circadian rhthyms are produced endogenously and they maintain themselves even without external time signs. At the head of this system, there is a main clock located in the suprachiasmatic nucleus of the anterior hypothalamus. Short wave lengths perceived as blue color are the strongest synchronizing agent for the circadian system which synchronizes most of the biological and psychological rhythms internally. Other stimulants are temperature, hunger-satiety, rest, physical activity and environmental effects. However, the effects of these stimulants are much weaker compared to light. Circadian rhythm is important for the optimal function of organisms and circadian sleep-wake disorders or chronic misalignment can oftan lead to psychiatric and neuro degenerative disease. Relatively recent environmental changes such as technology, diet, and lifestyle make many people prone to circadian system disruption. Artificial lighting, jet-lag, shift work and 24 hours Access to high-energy foods are a few factors that can negatively affect the health of modern societies by disrupting the circadian rhythm. While exposure to blue light is important to maintain the organism's well-being, alertness and cognitive performance during the day, chronic exposure to low-intensity blue light just before bed time can have serious effects on sleep quality, circadian 
phase and cycle times. In modern society, social jet-lag and nocturnal blue light exposure indicate that circadian misalignment and sleep disturbances have emerged as major health problems.

Keywords: Blue light, Circadian disruption Circadian rhythm, Melatonin, Metabolism, Nutrition.

\section{Giriş}

Biyolojik ritimler, siyanobakterilerden insanlara kadar birçok canlının dış dünyada tekrarlayan fiziksel etkenlere karşı gösterdikleri döngüsel, kimyasal, fizyolojik ve davranışsal yanıtlardır. Döngü sürelerine göre bu yanitlar; ultradiyen, sirkadiyen, infradiyen ve sirkannual gibi alt gruplara ayrılır. Ultradiyen bir günde birden fazla döngüsü olan, infradiyen haftalar ya da aylar süren, sirkannual ise yılda bir tekrar eden ritimler anlamına gelir [1]. Latin dilinde circa: yaklaşık, dies: bir gün anlamına gelen sirkadiyen ritim 24 saatte bir kendini tekrar eden periyodik kalıplardır [2].

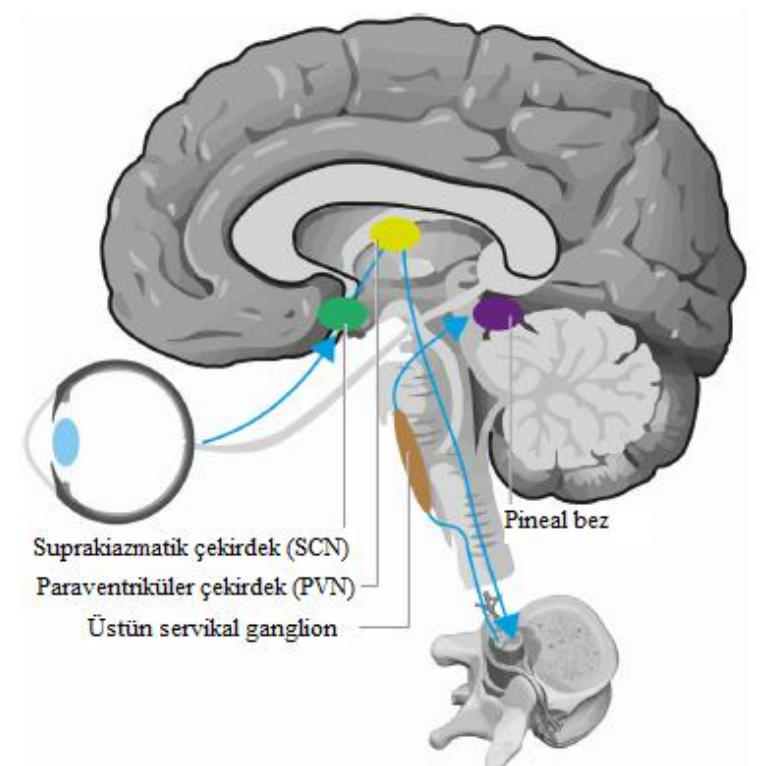

Şekil 1. Sirkadiyen bilginin sinyal yoluyla iletimi [3].

Gerçek 1şı̆̆a duyarlı retinada bulunan gangliyon hücreleri, melanopsin kaynaklı bir sinyali; retinohipotalamik (Şekil 1'de mavi renk ile gösterilen) yoluyla, suprakiazmatik çekirdekteki (Şekil 1'de yeşil renk ile gösterilen), insan "ana saati" olan hipotalamik pacemarker nöronlarına iletir. Sirkadiyen bilgi; paraventriküler çekirdek (Şekil 1'de sarı renk ile gösterilen), vertebral gri maddede intermediolateral hücre sütunu, üstün servikal ganglion (Şekil 1'de kahverengi ile gösterilen) yoluyla melatonin sekresyonundan sorumlu olan epifiz bezine (Şekil 1'de mor renk ile gösterilen) aktarılır [3].

Sirkadiyen ritimler, günlük ritimlerden farklı olarak endojen olarak üretilir ve diş zaman işaretleri olmasa bile kendilerini devam ettirirler [4]. Bu sistemin başında ön hipotalamusun suprakiazmatik nükleusunda (SCN) bulunan bir ana saat vardır [5]. SCN, olağanüstü salınım özelliğine sahip 15.000-20.000 nöron içerir [6]. D1ş dünya ile senkronize olmayı sağlayan SCN tarafindan üretilen bu 24 saatlik ritmin memelilerdeki en güçlü uyarıcısı (Zeitgeber), 1şıktır. Diğer uyarıcılar; sıcaklık, yemek yeme/açlık, dinlenme/aktivite ve sosyal ipuçlarıdır fakat bu uyarıcıların etkileri 1 şı ile karşılaştırıldığında çok daha zayıftır [7]. Sirkadiyen ritimler; otonom, kendi kendini idame ettiren ve isiya duyarlı olmasının yanında dikkat çekici bir esnekliğe sahiptir. Beslenme sirkadiyen ritimleri moleküllerden davranışsal seviyeye kadar değiştirebilir [5]. Çoğu biyolojik ve psikolojik ritmi dahili olarak senkronize tutan sirkadiyen sistem için en güçlü senkronize edici ajan mavi renk olarak algılanan kısa dalga boylarıdır yani mavi 1şıktır. Bu dalga boyları sıradan bir akıllı telefonun emisyon spektrumuna eş değerdir. Sirkadiyen sistemin senkronizasyonu sadece 1şığın spektral bileşimine bağlı değildir, aynı zamanda 1şığa maruz kalma zamanlamasına ve yoğunluğuna da bağlıdır [3].

$\mathrm{Bu}$ çalışmanın amacı, günümüzde yaygın olarak kullanılan ve mavi 1şık yayan teknolojik cihazların vücudumuzu psikolojik, fizyolojik ve hormonal olmak üzere etkileyen sirkadiyen ritim üzerindeki etkilerini araştırıp derlemektir.

\section{Genel Bilgiler}

Sirkadiyen sistem, vücut dokuları boyunca moleküler saat ağlarından oluşur. Retina, koku alma ampulü ve mediobasal hipotalamus dahil olmak üzere birçok beyin çekirdeğinde, beynin içindeki periferik saatler (SCN olmayan beyin saatleri) bulunmuştur. SCN periferik saatleri; davranışsal, nöroendokrin ve otonomik yollarla koordine eder [6]. Merkezi ve periferik saatler birlikte hareket ederek hipotalamusa enerji homeostazını ayarlamak ve korumak için bilgi sağlar [5]. Optimal enerji homeostazı için, beyindeki SCN olmayan saatlerin de SCN ile senkronize olması önemlidir. Bu SCN olmayan saatler SCN ile senkronizedir. Ancak, kisitlı beslenme gibi bazı özel durumlarda $\mathrm{SCN}$ kontrolünden ayrılabilirler. SCN, diğer beyin çekirdekleri yoluyla vücudun geri kalanına iletilen sirkadiyen bir ritim üretir. DNA mikrodizileri, herhangi bir dokudaki transkriptomun yaklaşık \%8-10'unun SCN kontrolü altında olduğunu gösterir, bu da vücuttaki birçok işlemde sirkadiyen saatin önemini gösterir [7].

SCN'ye ek olarak, nerdeyse tüm doku ve organlarda bulunan periferik saat genleri fizyolojik fonksiyonların zamanlarını düzenler [4]. Periferik saatlerden bazıları kendi periyotlarını ayarlayabilseler de çoğu SCN'den gelen sinyallere göre fonksiyon gösterir [5]. Işık, SCN için önemli bir zamanlayıcı olsa da periferik organların günlük ritimleri ışığa duyarlı değildir [1]. Karaciğer gibi periferik doku saatleri, tüketilen besinin bileşimine ve tüketildiği zamana özellikle duyarlıdır. Sirkadiyen sistemin düzensizliği ve özellikle sirkadiyen ritimler arasındaki zamanlama ilişkilerinin kaybının, bazı kronik hastalıkların gelişimine katkıda bulunduğu düşünülmektedir. Enerji alımı ile harcamasının uyumlu olduğu ve saat ayarlı metabolik değişikliklerle senkronize edilmiş net beslenme/açlık döngüleri, sağlam davranışsal ve fizyolojik sirkadiyen ritimlerin 
sürdürülmesine ve sağlığın korunmasına yardımcı olur. Nispeten yakın tarihli çevresel değişiklikler, birçok kişiyi sirkadiyen sistem bozulmasına yatkın kılmaktadır. Yapay aydınlatma, yüksek hızlı trans-meridyen hareketi ile indüklenen jet-lag, vardiyalı çalışma ve yoğun enerji içerikli besinlere kolay erişim, sirkadiyen sistemi düzensiz hale getirerek modern toplumların sağlığını olumsuz yönde etkileyebilecek birkaç faktördür [5]. Genel olarak, sirkadiyen aksaklıklar yaşayan gece vardiyalı çalışanlar ve hem jet-lag hem de gece vardiyalı çalışmaktan potansiyel olarak muzdarip uçuş görevlilerinde sağlık riskini arttırdığı öne sürülmektedir [3].

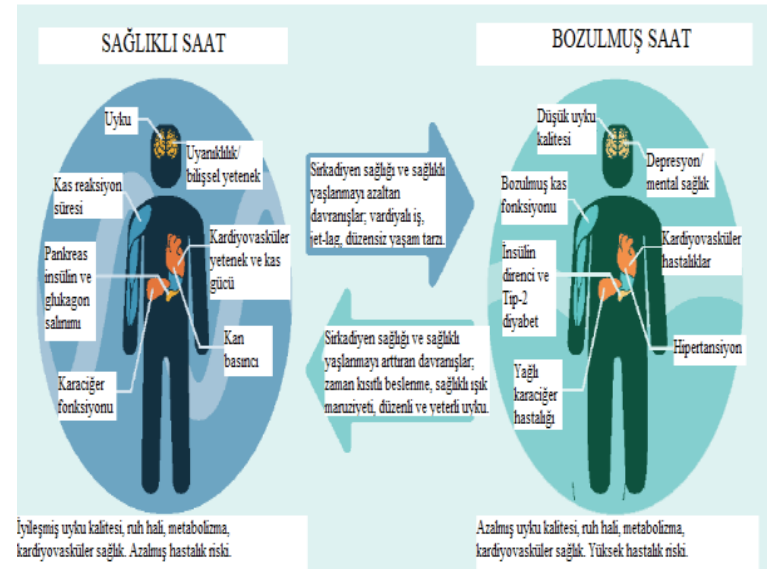

Şekil 2. Sağlıklı ve bozulmuş saatin etkileri [8].

Sirkadiyen ritmin kronik bozulmaları, insan sağlığını ciddi şekilde etkileme potansiyeline sahip olabilir. Örneğin; melatonin hormon seviyesinin azalması, kronik hastalıkların ve kanser, kalp ve damar hastalıkları, üreme, endometriozis, gastrointestinal ve sindirim sistemi sorunları, diyabet, obezite, depresyon, uyku yoksunluğu, bipolar spektrum bozuklukları ve bilişsel bozukluk gibi hastalıkların gelişiminde önemli bir rol oynar [3]. Bunun yanı sıra; sirkadiyen saat kontrolü, bağışılklk hücrelerinin taşınmasından doğuştan gelen ve edinilmiş bağışıklığın aktivasyonuna, konakçı-patojen etkileşimlerine kadar bağışıklık sistemini birçok yönüyle etkilemektedir [9]. Ayrıca, tüm cilt hücrelerinde bulunan saat genleri aracılığıyla sağlıklı bir cildi korumak için gerekli olan yolların da zamanlamasını sağlar. Doğal seyrinde gün boyunca cilt korunmaya odaklanır; gece ise cilt gündüz meydana gelen hasarları onarmaya ve ertesi sabaha hazırlanmaya odaklanır [10].

Besin tüketimi, günlük döngü içerisinde sadece belirli zaman aralıklarında gerçekleşir. Kanıt düzeyi yüksek bir çalışmada; zaman kısıtlı beslenmenin bir dizi metabolik yanıt için yararlı olduğunu, insülin direncini azalttığını ve glikoz toleransını arttırdığını göstermektedir. İnsanlarda daha ileri çalışmalara ihtiyaç duyulmasına rağmen, krono-beslenmenin olumlu etkileri dikkate alınmalıdır [6].

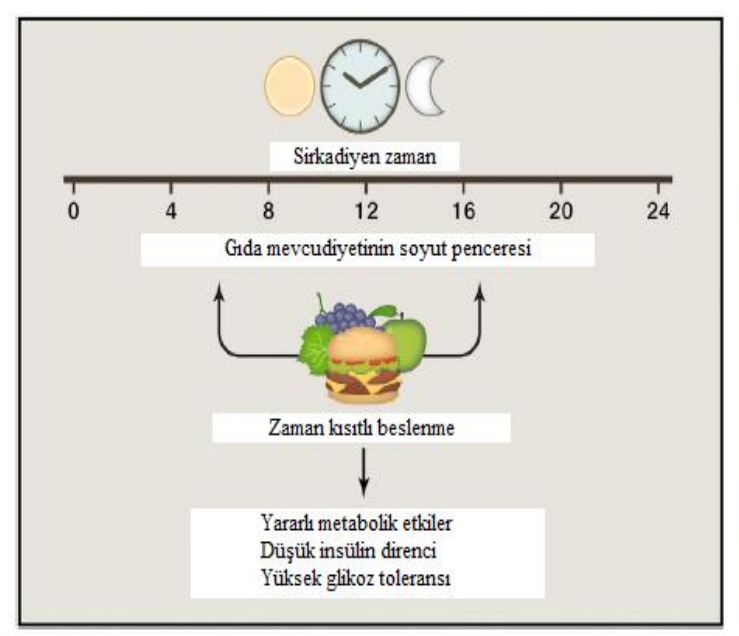

Şekil 3. Zaman kısıtlı beslenme ve yararlı etkileri [6].

Bununla birlikte açlık ve iştahın da belirli bir sirkadiyen döngüyü takip ettiği kanıtlanmıştır. Açlık hissinin en yüksek olduğu zaman 17:00-21:00, en düşük olduğu zaman ise 01:00-05:00 saatleri arasında olduğu bulunmuştur. Buna göre iştahı etkileyen birçok faktör vardır. Çünkü yiyecek alımı yalnızca enerji homeostazı süreçleri tarafından yönetilseydi, iştahımız aç kalınan bir gecenin ardından gelen sabah vaktinde en yüksek noktaya ulaşırdı. Bu çalışmalardan elde edilen bulgular, özellikle iştahı düzenleyen hormonal salgılar olan; iştahı uyarıcı ghrelin ve iştah bastırıcı leptin iştah düzenleme mekanizmaları ile uyumludur [11].

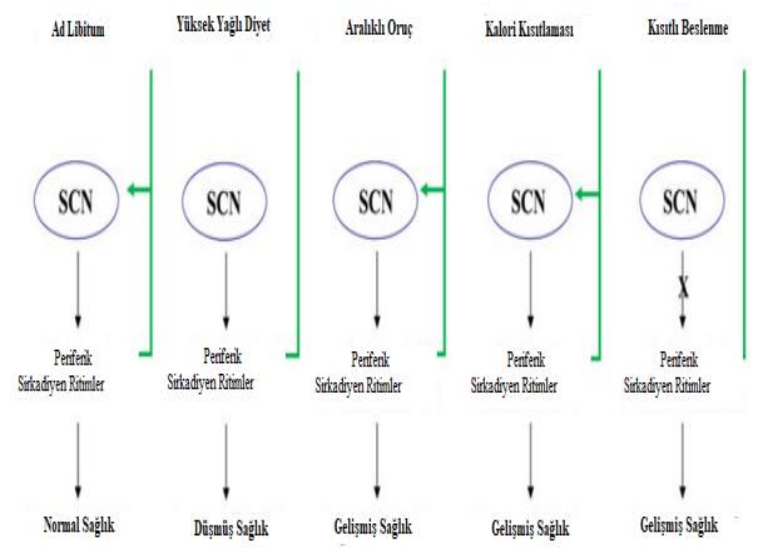

Şekil 4. Beslenme modellerinin sirkadiyen ritimler ve sağlık üzerine etkisi [12].

Fiziksel aktivite ile olduğu gibi, sirkadiyen sistem vücudu gündüz beslemek için hazırlar. İnsanın mide boşalması ve gastrointestinal motilite oranları sabahları zirveye ulaşır. Ayrıca, farelerin ve insanların bağırsak mikrobiyotasındaki günlük ritimler, günün zamanına özgü fonksiyonları yerine getirerek, aktif faz sırasında enerji metabolizmasını arttırır ve dinlenme fazında detoksifikasyonu desteklemektedir. 
Mikrobiyota ve sirkadiyen sistem karmaşık bir çift yönlü ilişkiye sahiptir, çünkü moleküler saatin bozulması bağırsak mikrobiyotasındaki ritmik değişiklikleri bozmaktadır. Ayrıca, bu değişikliklerin sağlıklı farelerde saat gen ekspresyonunu değiştirdiği bulunmuştur. Bu değişikliklerle ilgili olarak, glikoz ve lipitler gibi birçok besinin kan konsantrasyonlarında sirkadiyen ritmin etkisi bulunmaktadır. Gastrointestinal sistemin sirkadiyen düzenlenmesinin sonuçlarına örnek verilecek olursa; besin alerjisi test sonuçlarının günün saatine bağlıdır, beslenme ile ilişkili kan testleri açken ya da tokken farklı yorumlanır [5].

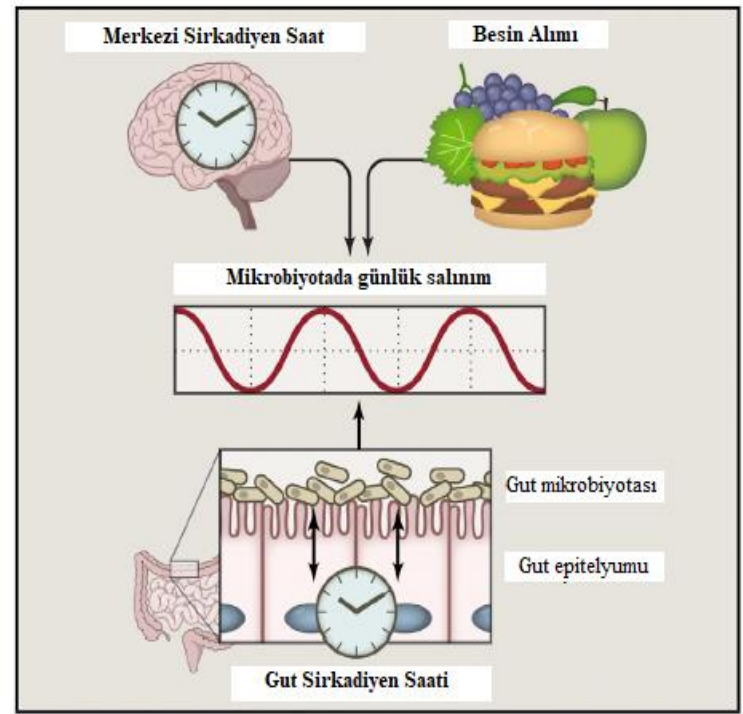

Şekil 5. Sirkadiyen saatin mikrobiyota ve bağırsak ile ilişkisi [6].

Bağırsak hücreleri, henüz tam olarak tanımlanamayan fizyolojik yollarla SCN'deki merkezi saate bağl1 güçlü bir sirkadiyen saat içerir. Beslenmenin döngüsel olması gibi besinlerin işlenmesi de bağırsak saatinin ritmik metabolizması ile gerçekleşir. Şekil 5 'te mikrobiyotanın gıda işlemeye katıldığ 1 ve bağırsak saati ile etkileşime girdiği gösterilmiştir. Bağırsak saatinin düzgün çalışması için mikrobiyotaya ihtiyaç duyması ve mikrobiyota seviyelerinin bağırsak döngülerini takiben salınması nedeniyle bu etkileşim çift yönlüdür. $\mathrm{Bu}$ nedenle, sirkadiyen saat, gıda ve bağırsak arasındaki ilişkide kritik bir bileşendir [6]. Sirkadiyen ritimlerin bozulmas1, gezgin ishali, peptik ülser, gastroözofageal reflü hastalığı, enflamatuar bağırsak hastalığı ve kolorektal kanser dahil çok çeşitli gastrointestinal rahatsızlıkları ve hastalıkları teşvik eden bir risk faktörü olabilir [13].

Fetüs ile yapılan sirkadiyen ritim çalışmalarında, fetüsün karanlık-aydınlık gibi zaman sinyallerini alamadıkları için annenin vücut sıcaklığı, hormon dağılımları ve besin alımları zamanlamalarına göre sirkadiyen ritmini ayarladığı görülmüştür. Buna göre fetüsün aslında maternal periferik osilatör olduğu yani fetal SCN tarafından sürüklenen endojen sirkadiyen saatler geliştirmek yerine; fetal organlardaki sirkadiyen fonksiyon, annenin sirkadiyen sistemi tarafindan kontrol edildiği düşünülmektedir [14].

\subsection{Sirkadiyen Sistemi Etkileyen Faktörler}

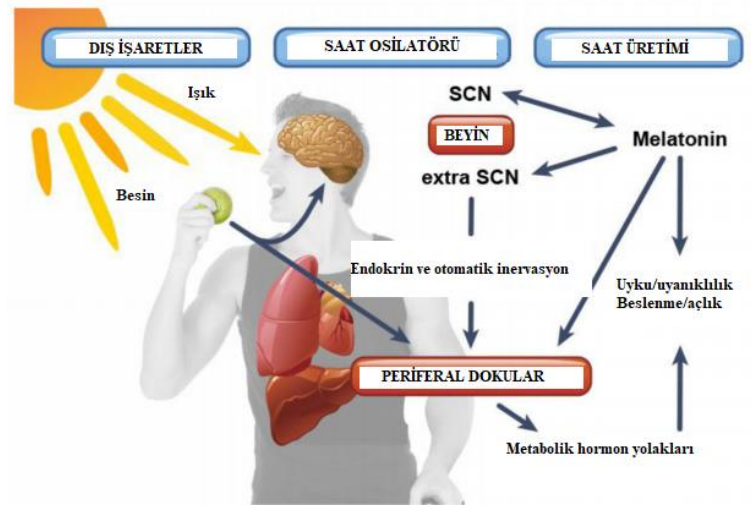

Şekil 6. Sirkadiyen ritimlerin iç ve diş işaretlerle düzenlenmesi [15].

Işık: SCN'yi direkt etkilediğinden sirkadiyen sistem için en önemli faktördür [1].

Melatonin: Dolaylı yoldan 1şıkla ilişkilidir. Pineal bez sayesinde karanlığın etkisiyle triptofandan melatonin sentezlenir. Gerçekleşen bu olay bütün memelilerde ritmiktir ve sentez karanlığın başlangıcından 1 şık başlangıcına kadar devam eder, gece saat 02:00-03:00 civarında pik yapar [1].

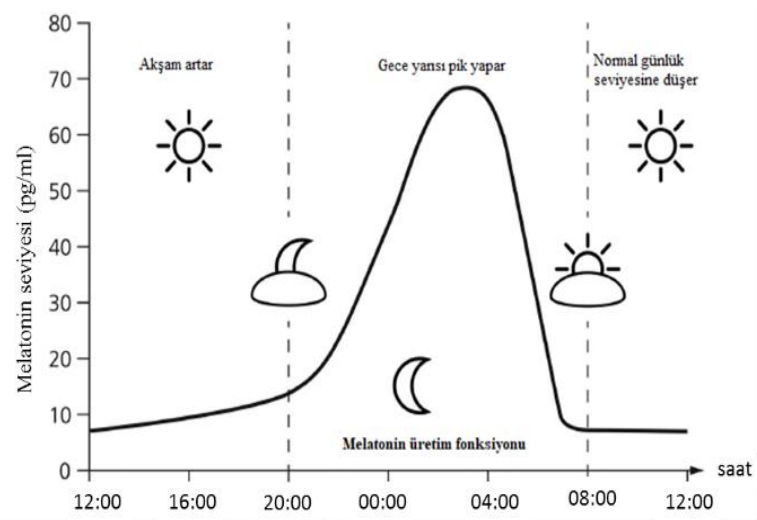

Şekil 7. 24 saatlik fizyolojik melatonin seviyeleri [3].

Akşamları azalan ışığa maruz kalma epifiz bezi tarafından melatonin üretiminin artmasıyla sonuçlanır ve gecenin ortasında pik seviyeleri normal gündüz seviyelerinden neredeyse on kat daha yüksektir [3].

Gece uykusu sırasında ortam ışığının varlığı sirkadiyen aksaklıklar ile ilişkili iken, sağlık riskinin azalması uzun uyku süresi ve körlük ile ilişkilidir. Ayrıca, prospektif kohort çalışmalarından elde edilen sonuçlar, ana melatonin metaboliti sülfatoksi melatoninin en düşük konsantrasyonuna sahip kadınların meme kanseri için en yüksek riske sahip olduğunu sürekli olarak göstermektedir [3]. Başka bir çalışmada, kısa uyku süresi sonrası adipositlerin insülin duyarlılığının, normal uyku süresi sonrası adipositlerin insülin duyarlılığı ile karşılaştırıldığında \%30 oranında daha az olduğu görülmüştür. $\mathrm{Bu}$ araştırmalar sonucunda, uykunun sadece beyin için değil aynı zamanda periferik fonksiyonlar için de faydalı olduğu ortaya çıkmıştır [16]. 
Sıcaklık: Çoğu organizma için sıcaklık güçlü bir uyarandır ve sirkadiyen sistemi etkiler. Fakat memelilerde dış sıcaklık değişimleri zayıf bir uyarandır [1].

Jet-Lag: Yüksek hizlı trans-meridyen hareketi ile indüklenen jet-lag, yolculuk sonucu iç saat ile varılan yerdeki aydınlık-karanlık döngüsü arasında uyuşmazlıklara neden olur [1,5]. Bireylerde yorgunluk, uykusuzluk, iştahsızlık, barsak bozukluğu, zaman ve uzaklık algı bozukluğu, tepki zamanının uzaması, terleme gibi sıkıntılar gözlemlenir [1]. Kafein, jet-lag sonrası yeni zaman dilimlerine senkronizasyonu hızlandırabilir [5].

Vardiyalı İş: Değişen yeme zamanı, 1şık zamanları ve uyku düzeni gibi çevresel sinyaller dengeli sirkadiyen sistemin sinyalizasyonunu bozabilir. Epidemiyolojik çalışmalar, vardiyalı çalışanların, büyük olasılıkla iç senkronizasyonun sonucu olan obezite ve Tip 2 diyabet dahil olmak üzere metabolik bozukluklar geliştirme riski daha yüksek olduğunu göstermiştir [7]. Dokuz saatlik gece vardiyası üzerine yapılan ilk çalışmalar, uyku zamanlamasındaki farklılıkların glikoz ve lipit düzeylerini kötüleştirdiğini bildirmiştir [2].

İnsanda sirkadiyen ritimleri değerlendirmek için kullanılan bugüne kadar belirlenmiş melatonin seviyeleri, vücut sıcaklığı ve dinlenme-aktivite döngüleri olmak üzere üç ana yöntem vardır. Klinik ortamda bu nesnel ölçütlerden bazılarının sınırlı kullanılabilirliği göz önüne alındığında, uyku günlükleri ve kronotip anketleri gibi araçlar da klinik uzmanlar tarafından tercih edilebilir. Okul/iş ve tatil günlerinden oluşan toplam 14 günlük uyku günlüğünün içerisinde yatağa gitme saati, uykuya dalma saati, uyanma saati, yataktan kalkma saati, kafein ve alkol tüketim saati, kullanılan ilaçlar ve ilaç saati, egzersiz saati gibi birçok bilgi içerir [17].

\subsection{Mavi Işık ve Sirkadiyen Ritim}

Görünür 1şık, hipotalamusun suprakiazmatik çekirdeklerindeki insan biyolojik saatini 24 saatlik güneş döngüsüne senkronize eder. Mavi renk olarak algılanan kısa dalga boyları, çoğu biyolojik ve psikolojik ritmi dahili olarak senkronize tutan sirkadiyen sistem için en güçlü senkronize edici ajandır. Sirkadiyen senkronizasyonun, uyku kalitesi, ruh hali ve bilişsel performans üzerindeki yararlı etkileri sadece 1 şık spektral bileşimine bağlı değildir, aynı zamanda maruz kalma zamanlamasına ve yoğunluğuna da bağlıdır. Gün boyunca mavi ışığa maruz kalma, epifiz bezi tarafından üretilen ve sirkadiyen ritim devamlılığında çok önemli rol oynayan hormon olan melatonin salgısının bastırılmasında etkindir. Mavi ışığa maruz kalma, gün içinde organizmanın refahını, uyanıklığını ve bilişsel performansını korumak için önemli olsa da, yatmadan hemen önce düşük yoğunluklu mavi 1şı̆ga kronik maruziyetin uyku kalitesi, sirkadiyen faz ve döngü süreleri üzerinde ciddi etkileri olabilir [3]. Modern toplumda sosyal jet-lag ve gece mavi ışı̆̆a maruz kalma artış1, sirkadiyen yanlış hizalama ve uyku bozukluklarının önemli sağlık sorunları olarak ortaya çıktığını göstermektedir [18].
Melatonin ritimleri de dahil olmak üzere sirkadiyen ritimler, derin uykuya dalışı kolaylaştırmanın farklı yönlerinde rol oynar. Vardiyalı çalışma sırasında geceleri yanlış zamanda kronik 1şık; 1şığa maruz kalma süresine, 1şığın dalga boyuna ve yoğunluğuna bağlı olarak sirkadiyen saat fazının kaymasına katkıda bulunabilir. Gün boyunca melatonin salgılanmasının baskılanmasının yararlı olduğuna inanılırken, gece böyle değildir. Sirkadiyen bozulma esas olarak iç sirkadiyen ritimler ile dış çevresel koşullar arasındaki yanlış hizalama ile karakterizedir. Sirkadiyen bozulma, uyku döngüsü ve vücuttaki dokulardaki periferikosilatörler ile asenkron SCN'yi de içerir, çünkü bu periferik saatler dokuya bağlı olarak düzensiz uyum sağlar. Işı̆̆a maruz kalma, sirkadiyen döngüde farklı zamanlarda uygulandığında faz ilerlemelerine veya gecikmelerine neden olabilir. Örneğin insanlarda, 05:00-17:00 arasındaki 1şık ilerlemeye ve bu aralığın dışındaki 1şık sirkadiyen saatte gecikmelere neden olur. Bu nedenle, yanlış zamanda kronik 1şık maruziyeti, sirkadiyen sistemin faz kaymasını indükleyebilir, diş çevresel koşullarla senkronizasyona izin vermez ve sirkadiyen bozulmaya yol açabilir, böylece hem hücresel hem de organ fonksiyonunu değiştirebilir [3].

Gece vardiyalı çalışmaların sınırlamaları göz önüne alındığında, çalışmalar gece vardiyası olmayan kişilerde geceleri 1şığa maruz kalmanın rolü de incelemiştir. Beden kütle indeksi, tipik ev ortamlarında gece 1şığa maruz kalmadan da artabilir. Örneğin, sadece üç lüksten daha yüksek gece 1şı̆̆ı seviyelerine maruz kalan katılımcılar önemli ölçüde daha fazla kilo almıştır, bel çevresi genişlemiştir vedüşük yoğunluklu lipoprotein (LDL)kolesterol seviyelerine sahiptir. İngiltere'de 100.000 kadın üzerinde yapılan bir çalışmada, obezite olasılığının gece 1şığına daha fazla maruz kalmasıyla birlikte arttığ1 bildirilmiştir [19].

Mavi ile zenginleştirilmiş beyaz 1şık ve beyaz 1şığa gün boyunca maruz kalma arasındaki etkiler karşılaştırıldığında, mavi ile zenginleştirilmiş 1şığın, Antartika'daki bir araştırma istasyonundaki personelin uyku başlangıcını (daha önce) ve uyku gecikmesini önemli ölçüde etkilediği görülmüştür. Mavi ile zenginleştirilmiş beyaz ışığın sirkadiyen ritmi senkronize ettiğini gösteren bu sonuç, mavi 1şığın melatonin supresyonunda diğer dalga boylarından daha verimli olduğunu gösteren diğer sonuçlarla doğrulanmıştır ve bu nedenle en güçlü uyaran (Zeitgeber) olarak görülebilir. Sonraki uyku gecesinin sonunda uyku derinliğinin değişmesi, sirkadiyen faz gecikmelerinin yatmadan önce 1şığa maruz kalınmasıyla indüklenebileceğini göstermiştir. Bu gecikmeler, mavi 1şı ğın yeşil 1 şıktan daha fazla etkisi ile uykuda devam etmektedir, bu da yatmadan önce mavi ışı̆̆a maruz kalmanın uykuyu etkileyebileceğini düşündürmektedir [3].

ISO 8980 'e göre mavi 1şık tehlikesi fonksiyonu, parlama işleminin fotoreversalini indüklemek için radyasyonun etkinliğine bağlı olarak insan gözünün mavi 1 ş1k tehlikelerine göreceli spektral duyarlılığını temsil eder. 


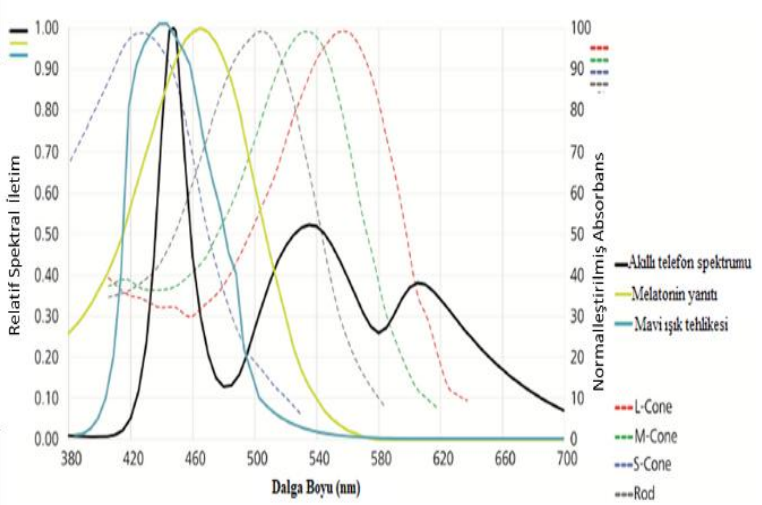

Şekil 8. Mavi ışık parlaklığının risk fonksiyonu [8].

Sıradan bir akıllı telefon ekranının maksimum parlaklık üzerindeki emisyon spektrumu, potansiyel olarak zararlı mavi tepe alanında ve melanopsin duyarlılığında belirgin bir çakışma gösterir. $460 \mathrm{~nm}$ aralığındaki kısa dalga boyları sirkadiyen sistemin faz kaymasında çok etkili olsa da, Şekil 8'de görüldüğü gibi 400 ila $440 \mathrm{~nm}$ aralığındaki yoğun mavi 1şık ağartmanın fotoreversal adı verilen bir fotokimyasal reaksiyon yoluyla retinaya da zarar vermektedir [3].

Okul çağı çocuklarında yapılan araştırmalarda internet ve telefonun aşırı kullanımı, sosyal ağ etkinlikleri, oyun konsolları ve televizyon izleme, yatak odasındaki cihaz sayısı ve kapanma süresi nedeniyle davranış ve uyku ile ilgili sorunlar incelenmiştir. Ekranların yaydığı ışığın spektral profili, sirkadiyen fizyolojiyi, uyanıklığı, bilişsel performans düzeylerini etkilemenin yanı sıra vücut ağırlığı artışı, metabolik bozukluk, depresyon, duygu durum bozuklukları, kanser ve kalp hastalığına yatkınlığ da arttırdığ1 görülmüştür [20].

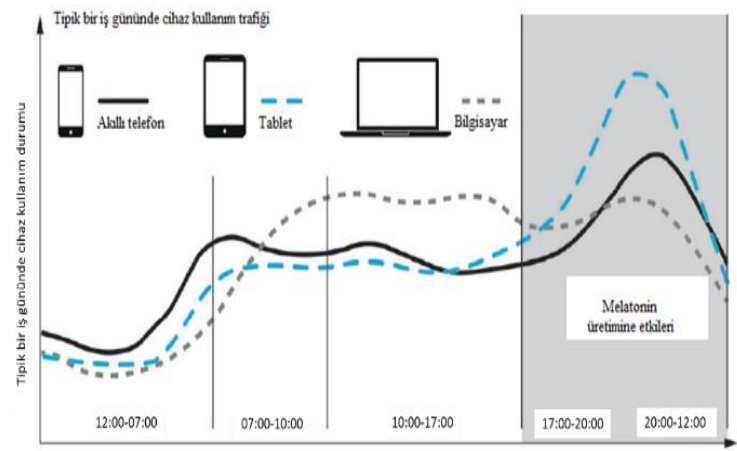

Şekil 9. Gün boyunca 1şık yayan cihaz kullanımı [3].

Cihaza bağlı web sitelerinin kullanım trafiği Şekil 9'da gösterilmiştir. Uykudan dört saat öncesine kadar mavi 1şığa maruz kalmanın gece melatonin düzeylerini ve subjektif uyku kalitesini etkileyebileceği bildirilmiştir. Melanopsinretina ganglion hücreleri mavi 1şığa karşı son derece duyarlıdır ve hatta akıllı telefondan veya 1 şık yayan e-okuyuculardan düşük 1 şı seviyelerine maruz kalmak sirkadiyen ritmin bozulmalarıyla ilişskilidir. Akıllı telefonların modern yaşamdaki varlığ 1 her geçen gün artmakta ve daha uzun ortalama ekran sürelerinin daha kısa uyku süresi ve daha kötü uyku verimliliği ile sonuçlandığı gösterilmiştir. Basılı kitaplarla karşılaştırıldığında, uykudan önce 1şık yayan bir e-kitap okumak, genç yetişkinlerde ( $25 \pm 3$ yaş) uykuya dalma süresini uzatmıştır. Yatmadan önce e-kitap okuyan bireylerde, hızlı göz hareketi uyku fazının gecikmesi ve azalmasıyla sirkadiyen saatin geciktiği görülmüştür. Melatonin kan konsantrasyonu seviyeleri bastırılmış ve ertesi sabah uyanıklık azalmıştır. Yatmadan hemen önce ışık yayan e-kitapların kullanımının o sırada uyanıklığ arttırdığı görülmüştür [3].

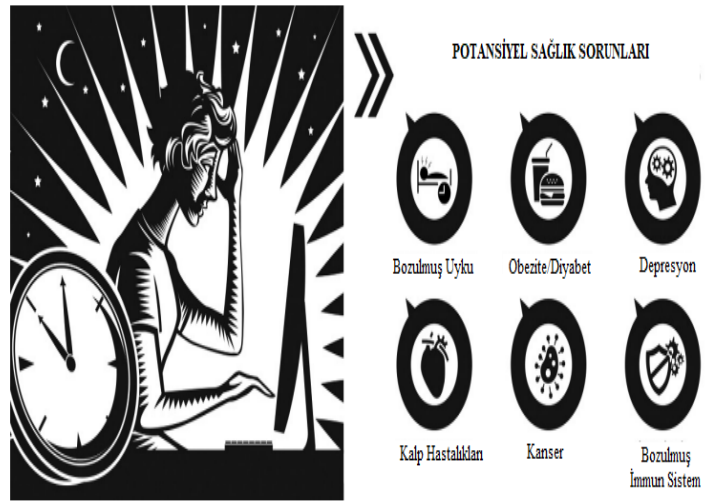

Şekil 10. Mavi ışığın sağlığa potansiyel etkileri [15].

Son zamanlarda sınırsız 1şık yayan cihaz kullanımı nedeniyle, melatonin supresyonunun artması ve gecikmiş sirkadiyen ritim zamanlaması, azalmış akşam uykusu ve artan sabah uykusu gibi benzer eğilimler bildirilmiştir. Mavi gündüz 1şı̆̆ının önleyici etkisinin, gün 1şığının diğer dalga boyu bileşiminden daha etkili olduğu kanıtlanmıştır. $\mathrm{Bu}$ bulguların sonuçları, melanopsin reseptörlerinin akşam ve gece saatlerinde özellikle hassas olmaları ve uyku bozukluklarının çoğunun akşamları yatmadan hemen önce düşük mavi işı maruziyeti ile ilişkili olabileceğini göstermektedir [3]. Akşam veya gece boyunca farklı kaynaklardan mavi 1şığa maruz kalınması ayrıca cilt hücrelerini potansiyel olarak gece ritimleriyle uyumsuz hale getirebilir, bu durum birçok hasara neden olabilir ve yaşlanmayı hızlandırabilir [10]. İnsanlarda, yapay 1şığa maruz kalmanın artmasıyla obezite ve diyabet artışları gözlemlenmiş ve akşam parlak 1şığın iştahı arttırdığı gösterilmiştir. Geceleri mavi yapay 1şı̆ga maruziyetin uyku-uyanıklık ve enerji metabolizmasının kontrolü üzerindeki etkisini değerlendirmeyi amaçlayan bir insan çalışması yapılmıştır. Bu çalışma sonucunda; enerji harcaması, oksijen tüketimi, karbondioksit üretimi ve kahvaltının termik etkisinin 1şı̆̆a maruz kalmayan bireylere göre geceleri mavi yapay 1şığa maruz kalanlar bireylerde önemli ölçüde düşük olduğu bildirilmiştir [21].

Düşük yağlı beslenen ve yüksek yağlı, yüksek sükrozlu beslenen dişi ve erkek fareler üzerinde geceleri mavi yapay 1şığa (bALAN) maruz kalmanın etkileri ile ilgili yapılan çalışmanın sonuçları özellikle geceleri yapay ışığa maruz kalmanın erkek farelerde, uzun vadede diyabet gelişimine yol açabilen glikoz metabolizmasını bozduğunu göstermektedir. Diyetin her bir bileșeni ayrı ayrı analiz edildiğinde, geceleri bir saatlik mavi yapay 1şı maruziyetinden sonra erkek farelerde karanlık fazda 
belirgin bir şeker tüketimi ile ilişki bulunmuştur. Bu sonuç, mavi 1şı̆̆ın cinsiyete bağlı bir şekilde lezzetli yiyecek alımını düzenleyen belirli beyin bölgelerini etkileyebileceğini düşündürmektedir. Mavi ışı̆̆a gece maruz kaldıktan sonra, diyet türü ne olursa olsun, plazma insülin düzeylerinde azalma ile birlikte Arvicanthis erkeklerinde artmış glikoz seviyeleri gözlenmiştir. Bu sonuçlara göre noktürnal 1şığın insülin salınımını inhibe ederek glikoz toleransı üzerindeki olumsuz etkilerini daha da vurgulanmıștır [21].

\subsection{Sirkadiyen Ritim ve Beslenme}

Beslenme programı, periferik organlardaki sirkadiyen saatler üzerinde belirgin bir etkiye sahip olduğundan, beslenme zamanı ve sirkadiyen saatler birbirine sık1 sıkıya bağlıdır. Gece hayvanlarından beklendiği gibi, fareler çoğunlukla gece boyunca yiyecek tüketir. Yalnızca gün içinde yiyecek sağlandığında, çevresel saatlerin fazı birkaç gün içinde kademeli olarak tersine çevrilir. Buna karşın, ters çevrilmiş beslenme rejiminin beyindeki ana saatin fazı üzerinde çok az etkisi vardır. Bu nedenle, beslenme-oruç döngüleri, beyindeki ana saat tarafindan yayılan aksi halde baskın olan senkronizasyon sinyallerini atlayarak, çevresel saatler için güçlü zamanlama işaretleri olarak işlev görüyor gibi görünmektedir. Beslenmenin sirkadiyen ritmiklik üzerindeki belirgin etkisi, ad libitum ile beslenen farelerde sirkadiyen gen ekspresyonunu zaman kısıtlamalı besleme rejimi altında karşılaştıran çalışmalardan da anlaşılmaktadır. Dahası, diyet bileşiminin farelerde ve sıçanlarda ritmik beslenme davranışı üzerinde bir etkisi olduğu görülmektedir. Yüksek yağlı beslendikten sonra, fareler, saat eksikliği olan farelere çok benzer şekilde değişen beslenme-açlik döngüleri sergiler [6].

Beslenme üzerine yapılan birçok araştırma, yutulan gıdanın miktarı ve kalitesinin organizmanın refahı üzerindeki etkisini kapsamlı bir şekilde incelemiştir. Günümüzde bu parametrelerin kritik olduğu ve değişikliklerinin morbidite ve mortalite ile ilişkili olduğu yaygın olarak kabul edilmektedir (örneğin, yüksek yağlı diyet). Son yillarda elde edilen kanıtlar, yemek zamanlamasının uyku-uyanma döngüsü, çekirdek vücut 1SıS1, performans ve uyanıklık gibi çok çeşitli fizyolojik süreçleri etkileyebileceğini göstermektedir [6]. Yapılan araştırmalarda beslenme-oruç döngülerinin, beyindeki ana saati bile atlayarak karaciğer saati için ana zamanlama ipuçları olduğunu göstermiştir. İşte bu nedenle değişen beslenme koşulları altında ana ve çevresel saatlerin uyumsuzluğunun organizmaların homeostazını bozduğu ve onları kronik hastalıklara yatkın hale getirdiği hipotezi ileri sürülmüştür [22]. Bu nedenle, "krono-beslenme" vücudun günlük ritimleriyle koordineli olarak gida tüketimi olarak tanımlanan "krono-beslenme" kavramı ortaya çıkmıştır. Bu kavram, yiyecek miktarı ve içeriğine ek olarak, yeme zamanının da bir organizmanın sağlığı için kritik olduğu temel fikrini yansıtır. Zamanla sinırlı besleme deneyleri, beslenme programının metabolik etkilerini daha da vurgulamıştır [6]. Son yıllarda, sirkadiyen saat ve beslenme döngüleri tarafından yönetilen transkripsiyonel düzenleme üzerine birçok çalışma yapılmıştır. Örneğin, gen ekspresyonundaki ve metabolit birikimindeki ritmiklik, kısıtlı bir besleme rejimi ile saat eksikliği olan farelerde kismen onarilabilir. $\mathrm{Bu}$ beslenme kısitlaması, gen ekspresyonunda ve metabolizmada ritmikliği pekiştirir ve yüksek yağlı bir diyet rejiminde kalori alımını azaltmadan obeziteye karşı koruma sağlayabilir [22].

Düzenli besin tüketen vahşi tip fareler ile gece kısıtlı beslenen fareler karşılaştırıldığında, gece kısıtlı beslenenlerde hepatik trigliserit içeriği \%50 azalırken, toplam günlük kalori tüketimi etkilenmez. Zaman kısıtlamalı yüksek yağlı diyet uygulanan fareler, ad libitum erişime sahip farelerle eşdeğer kalori tüketir, ancak obezite, hiperinsülinemi, hepatik steatoz ve iltihaplanmaya karşı korunur. Yalnızca aktif faz boyunca gıda bulunabilirliğindeki değişikliklerin bile (örneğin kahvaltıya karşı akşam yemeği) vücut ağırlığını etkilediği bildirilmiştir. Kemirgenlerde yapılan ek çalışmalar, erken gece oruç tutmanın vücut ağırlığını artırdığını, ancak geç gece oruç tutmanın vücut ağırlığ artışını azalttığını göstermiştir. Yakın zamanda yapılan bir çalışmada, iki eşit enerji içeriğine sahip bir program ile zayıflama diyeti uygulayan grubun karşılaştırılması, daha büyük bir kahvaltı ve tam tersine göre daha küçük bir akşam yemeği verilen grupta metabolik belirteçlerde daha fazla gelişme olduğunu ortaya koymuştur. Başka bir çalışma, erken yemek zamanlarının serum lipit seviyelerini önemli ölçüde düşürdüğünü göstermiştir Birçok insan epidemiyolojik çalışması, yeme alışkanlığ ile obezite arasında bir korelasyon tespit etmiştir. Örneğin, büyük bir kohort çalışmasında ergenler arasında kahvaltı tüketimi vücut ağırlığı artışı ile ters orantılı bulunmuştur. Birkaç çalışma, kısa uyku süresi ( $<5$ saat) veya geç uyuyanlar (uykunun orta noktası $>05: 30$ ) ile geç akşam yemeği yemek / akşam geç saatlerde daha fazla enerji tüketimi arasında bir ilişki olduğunu ve obezite ve diyabet gelişimi için önemli ölçüde daha yüksek risk olduğunu göstermiştir. İlginç bir şekilde, hem insanlarda hem de sıçanlarda yapılan çalışmalar, akşam yemeğinde kahvaltı saatine göre daha yüksek yağ bileşimi için seçilmiş yiyecek tercih edildiğini göstermiştir, bu da gece geç beslenmeyle ilişkili obeziteye yol açabilecek bir durumdur. $\mathrm{Bu}$ çalışmalar geç vakitte yemek yemenin insanlarda obezite riskini arttırdığını göstermektedir. Ancak, zaman sınırlı beslenmenin etkileri henüz insanlarda ayrıntılı olarak incelenmemiştir. İnsan çalışmalarının daha uzun süreli planlanması, mevcut kanıtlar ile kontrollü değerlendirme yapılması önemlidir [6].

\section{Sonuc}

Günümüzde artan obezite, tip 2 diyabet gibi metabolik hastalıklardan kansere kadar vücutta oluşan patolojik durumlar sirkadiyen ritimden etkilenmekte ve sirkadiyen ritmi etkilemektedir. Sirkadiyen ritmi sekteye uğratan en önemli etmenlerden biri 21. yüzyılda hızla yayılan telefon, tablet, televizyon gibi mavi 1şı yayan teknoloji aletleridir. Bu cihazlara gece maruz kalmak sirkadiyen ritimde düzensizliğe ve uyumsuzluğa neden olarak 
birçok hastalığın oluşmasına zemin hazırlamaktadır. Yaşam tarzında yapılan küçük değişiklerle sirkadiyen sistemin düzenlenmesi ve yaşam kalitesinin artması sağlanabilir. Sadece geceleri mavi yapay ışığa maruziyet engellenerek;

- enerji metabolizması kontrol altına alınabilir, vücudun yağ depolaması azaltılabilir.

- şeker yeme isteği bunun sonucunda kilo kontrolü ve diyabet başta olmak üzere diğer hastalık riskleri azaltılabilir.

- iştah ve kilo kontrolü daha kolay sağlanabilir, bunun sonucunda obezite, diyabet gibi diğer metabolik hastalıklara sahip olma riski azaltılabilir.

- kolesterol yüksekliği kontrol altında tutulabilir ve bel çevresinin genişlemesi engellenebilir.

- hormonal homeostaz daha kolay sağlanır ve hormonal bozulmaların önüne geçilebilir.

- uyku kalitesi arttırılabilir ve ertesi sabah ruh halinin iyileşmesine, verimliliğin arttırılmasına yardımcı olunabilir.

- biyolojik ritmin düzenlenmesinin yanı sıra psikolojik ritim de düzenlenerek mental sağlığın iyileşmesi sağlanabilir.

- bilişsel performans iyileştirilebilir.

- cilt sorunları ve erken yaşlanmanın etkileri azaltılabilir.

Referanslar

1.Sözlü, S, Sanlıer, N, Sirkadiyen Ritim, Sağlık ve Beslenme İlișkisi, Turkiye Klinikleri Journal of Health Sciences, 2017, 2(2), 100-9.

2.Poggiogalle, E, Jamshed, H, Peterson, C.M, Circadian Regulation of Glucose, Lipid, and Energy Metabolism in Humans. Proceedings of the Nutrition Society, 2018, 73(3), 223-229.

3.Wahl, S, Engelhardt, M, Schaupp, P, Lappe, C, Ivanov, I.V, The iner clock-Blue light sets the human rhythm, Journal of Biophotonics, 2019, 1-14.

4.Yüksel, A, Sirkadiyen Ritim ile Yeme Zamanı İlişkisi, Journal of Health Professionals Research, 2018, 1(1), 38-43.

5.Potter, G.D.M, Cade, J.E, Grant, P.J, Hardie, L.J, Nutrition and the Circadian System, British Journal of Nutrition, 2016, 116(3), 434-42.

6.Asher, G, Sassone-Corsi, P, Time for Food: The Intimate Interplay between Nutrition, Metabolism, and the Circadian Clock, Cell, 2015, 161(1), 84-92.

7.Oosterman, J.E, Kalsbeek, A, Fleur, S.E, Belsham, D.D, Impact of nutrients on circadian rhythmicity, American Journal of Physiology, 2015, 308(5), 337-350.

8.Manoogian, E.N.C, Panda, S, Circadian rhythms, time-restricted feeding, and healthy aging, Ageing Research Reviews, 2017, 39, 5967.

9.Rijo-Ferreira, F, Takahashi, J. S, Genomics of circadian rhythms in health and disease, Genome Medicine, 2019, 11(1).

10. Dong, K, Goyarts, E. C, Pelle, E, Trivero, J, Pernodet, N, Blue Light disrupts the circadian rhythm and create damage in skin cells, International Journal of Cosmetic Science, 2019, 41, 558-62.

11. Marangoni, F, Martini, D, Scaglioni, S, Sculati, M, Donini, L.M, Leonardi, F, Poli, A, Snacking in nutrition and health. International Journal of Food Sciences and Nutrition, 2019, 1-15.

12. Froy, O, Circadian rhythms, nutrition and implications for longevity in urban environments, Proceedings of the Nutrition Society, 2017, 77(03), 216-22.

13. Voigt, R.M, Forsyth, C.B, Keshavarzian, A, Circadian rhythms: a regulator of gastrointestinal health and dysfunction, Expert Review of Gastroenterology \& Hepatology, 2019, 1747-4124.
14. Crew, R.C, Mark, P.J, Waddell, B.J, Epigenetic regulation of the fetal circadian clock, Nutritional Epigenomics, 2019, 211-29.

15. Lunn, R.M, Blask, D.E, Coogan, A.N, Figueiro, M.G, Gorman, M.R, Hall, J.E, Boyd, W.A, Health consequences of electric lighting practices in the modern world: A report on the National Toxicology Program's workshop on shiftwork at night, artificial light at night, and circadian disruption, Science of The Total Environment, 2017, 607-608, 1073-1084.

16.Hernández-García, J, Navas-Carrillo, D, Orenes-Piñero, E, Alterations of circadian rhythms and their impact on obesity, metabolic syndrome and cardiovascular diseases, Critical Reviews in Food Science and Nutrition, 2019, 1-10.

17.Reid, K.J, Assessment of Circadian Rhythms, Neurologic Clinics, 2019, 37(3), 505-26.

18.Nagai, N, Ayaki, M, Yanagawa, T, Hattori, A, Negishi, K, Mori, T, Nakamura, T.J, Suppression of Blue Light at Night Ameliorates Metabolic Abnormalities by Controlling Circadian Rhythms, Investigative Ophthalmology and Visual Science, 2019, 60(12), 3786-93.

19.Nelson, R.J, Chbeir, S, Dark matters: effects of light at night on metabolism. Proceedings of the Nutrition Society, 2018, 77(3), 223229.

20. Olteanu-Pascal, D, Nadejda L, The influence of light from gadgets on circadian rhythm in children, The 8th International Medical Congress for Students and Young Doctors, 2020, 248-249.

21. Masís-Vargas, A, Hicks, D, Kalsbeek, A, Mendoza, J, Blue light at night acutely impairs glucose tolerance and increases sugar intake in the diurnalrodent Arvicanthisansorgei in a sex-dependent manner, Physiological Reports, 2019, 7(20), 1-19.

22. Atger, F, Gobet, C, Marquis, J, Martin, E, Wang, J, Weger, B, et al., Circadian and feeding rhythms differentially affect rhythmic mRNA transcription and translation in mouse liver, Proceedings of the National Academy of Sciences, 2015, 112(47), E6579-E6588.

http://edergi.cbu.edu.tr/ojs/index.php/cbusbed isimli yazarın CBU-SBED başlıklı eseri bu Creative Commons Alınt1-Gayriticari4.0 Uluslararası Lisansı ile lisanslanmıștır. 